\title{
Perbandingan Pengencer Tris Kuning Telur dan Susu Skim Kuning Telur Terhadap Persentase Motilitas, Viabilitas dan Integritas Membran Plasma Spermatozoa Kambing Sapera pada Penyimpanan Suhu $5^{\circ} \mathrm{C}$
}

\section{The Difference of Tris Egg Yolk and Skim Milk Egg Yolk Diluent on The Percentage of Motility, Viability and Plasma Membrane Integrity of Spermatozoa Sapera Goat on Storage of $5^{\circ} \mathrm{C}$ Temperature}

\author{
Novia Nur Iskandari ${ }^{1 *}$, Sri Pantja Madyawati ${ }^{1}$, Prima Ayu Wibawati ${ }^{2}$, Tri Wahyu \\ Suprayogi ${ }^{1}$, Ragil Angga Prastiya ${ }^{1}$, Bodhi Agustono ${ }^{3}$ \\ ${ }^{1}$ Departemen Reproduksi, ${ }^{2}$ Departemen Kesehatan Masyarakat Veteriner, ${ }^{3}$ Departemen Peternakan, \\ PSDKU Banyuwangi, Universitas Airlangga \\ Jl. Wijayakusuma No.113, Mojopanggung, Giri, Banyuwangi, Jawa Timur 68425 \\ *Corresponding author: novianur443@gmail.com
}

\begin{abstract}
Abstrak
Penelitian ini bertujuan untuk mengetahui perbedaan pengencer tris kuning telur dan susu skim kuning telur terhadap persentase motilitas, viabilitas dan integritas membran plasma spermatozoa kambing Sapera. Metode penelitian dengan mengumpulkan semen, pemeriksaan kelayakan semen segar, pengenceran semen, penyimpanan suhu $5^{\circ} \mathrm{C}$ dan pemeriksaan setiap 24 jam. Data diolah menggunakan anova faktorial dengan membandingkan antara dua bahan pengencer terhadap waktu pemeriksaan. Data menunjukkan tris kuning telur signifikan $(\mathrm{p}<0.05)$ terhadap susu skim kuning telur. Lama penyimpanan menunjukkan hasil signifikan pada hari ke-1 aspek motilitas 84.44\%: $80 \%$, viabilitas 89.67\% : 86\% dan integritas membran plasma 83.67\%: 79.33\%. Tris kuning telur dan susu skim kuning telur menunjukkan adanya interaksi $(\mathrm{p}<0.05)$ terhadap waktu pemeriksaan motilitas namun tidak terdapat interaksi $(p>0.05)$ terhadap waktu pemeriksaan viabilitas dan integritas membran plasma. Disimpulkan pengencer tris kuning telur dan susu skim kuning telur berpengaruh pada persentase motilitas, viabilitas dan integritas membran plasma spermatozoa.
\end{abstract}

Kata kunci: spermatozoa, kambing Sapera, tris kuning telur, susu skim kuning telur

\begin{abstract}
This study aimed to determine the difference of egg yolk diluent and egg yolk skim milk on the percentage of motility, viability and integrity of the spermatozoa plasma membrane of Sapera goats. The method of this study was collecting semen, fresh semen feasibility examination, dilution of semen, storage temperature of $5^{\circ} \mathrm{C}$ and examination every 24 hours. Data were analyzed using factorial Anova by comparing the two diluents with examination time. Data showed significant on egg yolk tris ( $p<0.05)$ to egg yolk skim milk. The examination time showed significance at 24 hours with motility $84.44 \%: 80 \%$, viability $94.67 \%: 93.88 \%$ and plasma membrane integrity $83.67 \%: 79.33 \%$. Tris egg yolk and egg yolk skim milk showed an interaction $(p<0.05)$ on the motility examination time but there was no interaction $(p>0.05)$ on the time of examination of viability and plasma membrane spermatozoa integrity of Sapera goats. It can be concluded that egg yolk diluent had better than egg yolk skim milk on the percentage of motility, viability and integrity of the Sapera goat spermatozoa plasma membrane.
\end{abstract}

Keywords: Sapera goat, spermatozoa, egg yolk tris, skim milk egg yolk

Received: 30 Januari 2020

Revised: 7 Maret 2020

Accepted: 11 April 2020

\section{PENDAHULUAN}

Kambing adalah salah satu ternak ruminansia kecil yang berperan dalam kehidupan masyarakat petani. Jenis kambing yang mempunyai potensi dwiguna yaitu kambing Sapera. Kambing Sapera adalah hasil persilangan kambing jantan Saanen dengan 
kambing betina Peranakan Etawa (PE). Puncak produksi susu induk kambing Sapera mencapai 2-4 liter/hari sedangkan kambing peranakan Etawa menghasilkan 2-3 liter/hari (Rusdiana dkk., 2015; Saputro dkk., 2018). Ditjen Peternakan telah melakukan sejumlah upaya untuk mendorong pengembangbiakan ternak kambing perah dengan teknologi inseminasi buatan. Teknik inseminasi buatan yang sudah banyak dipakai yaitu menggunakan semen beku maupun semen cair (Deviana dkk., 2018).

Inseminasi Buatan merupakan teknik memasukkan semen ke dalam saluran reproduksi betina menggunakan alat yang disebut Insemination Gun yang bertujuan untuk meningkatkan mutu genetik ternak, populasi, produksi, pendapatan dan mengurangi penyakit kelamin menular (Hardijanto dkk., 2010). Penggunaan semen cair pada daerah yang sulit mendapatkan nitrogen cair, dapat memanfaatkan teknik inseminasi buatan menggunakan kambing bibit unggul yang ada di daerah tersebut dengan menambahkan jenis pengencer yang sesuai dan disimpan dalam suhu $5^{\circ} \mathrm{C}$ (Susilowati dkk., 2010). Pengenceran spermatozoa akan mempertahankan kualitasnya dan dapat digunakan untuk menginseminasikan betina lebih banyak karena volume semen ditingkatkan (Trias, 2001).

Pengencer yang umumnya digunakan yaitu tris kuning telur dan susu skim kuning telur karena telah memenuhi syarat pengenceran yaitu mengandung nutrisi untuk spermatozoa, melindungi membran spermatozoa dari cold shock dan bersifat buffer (Ari et al., 2011). Pengencer kuning telur mengandung lipoprotein dan fosfolipid yang mempertahankan serta mencegah kerusakan membran spermatozoa pada proses pembekuan dan susu skim memiliki kasein yang dapat melindungi spermatozoa selama penyimpanan pada suhu rendah (Allai et al., 2015).

Perlu dilakukan evaluasi perbedaan pengencer tris kuning telur dan susu skim kuning telur terhadap motilitas, viabilitas dan integritas membran plasma semen kambing Sapera yang di simpan pada suhu $5^{\circ} \mathrm{C}$ berkaitan dengan kualitas semen yang dihasilkan sebagai syarat semen cair.

\section{METODE PENELITIAN}

\section{Alat dan Bahan}

Sampel penelitian menggunakan semen dari 1 ekor kambing Sapera berumur 2 tahun dengan 2 perlakuan dan 9 kali pengambilan. Bahan yang digunakan untuk pemeriksaan makroskopis dan mikroskopis antara lain Eosin Nigrosin Merck $^{\circledR}$, $\mathrm{NaCl}$ Otsuka ${ }^{\circledR}$, Na Sitrat Emprove ${ }^{\circledR}$ exp, aquades dan fruktosa Merck $^{\circledR}$. Bahan pengencer tris kuning telur: aquades $80 \mathrm{ml}$, laktosa $1.4 \mathrm{gr}$, antibiotik (Penicilin Meiji ${ }^{\circledR} 1000 \mathrm{IU} / \mathrm{ml}$ dan Streptomicin Meiji ${ }^{\circledR} 1 \mathrm{mg} / \mathrm{ml}$ ), tris amino methane Merck $^{\circledR} 1.6$ gr, raffinosa pentahydrate Merck $^{\circledR} 2.5$ gr, asam sitrat Emprove ${ }^{\circledR} 0.9 \mathrm{ml}$ dan kuning telur $20 \mathrm{ml}$. Bahan pengencer susu skim kuning telur: susu bubuk skim Tropicana Slim ${ }^{\circledR}$ 10 gram, aquades $100 \mathrm{ml}$, antibiotik (Penicilin Meiji $^{\circledR} 1000 \mathrm{IU} / \mathrm{ml}$ dan Streptomicin Meiji ${ }^{\circledR}$ $1 \mathrm{mg} / \mathrm{ml}$ ) dan kuning telur $5 \mathrm{ml}$.

\section{Penampungan Semen Kambing Sapera}

Pengambilan semen dilakukan dengan menggunakan vagina buatan kambing, sebelum dilakukan penampungan preputium dibersihkan menggunakan air hangat. Semen yang berhasil ditampung dilakukan pemeriksaan kelayakan kemudian dibagi dua bagian. Bagian pertama dicampur dengan tris kuning telur sedangkan bagian kedua menggunakan susu skim kuning telur. Semen yang berhasil ditampung rata-rata $0.87 \mathrm{ml}$.

\section{Pemeriksaan Semen Segar}

Pemeriksaan makroskpis terdiri dari volume, bau, warna, $\mathrm{pH}$ dan konsistensi. Volume diketahui dengan melihat skala pada tabung penempungan semen, bau diketahui dengan menggunakan indra pembau pada tabung penampungan, warna dengan melihat semen pada tabung penampungan pada suasana terang, $\mathrm{pH}$ dengan menggunakan $\mathrm{pH}$ indikator dan konsistensi diketahui dengan cara memiringkan tabung berisi semen dan dikembalikan pada posisi semula. 
Pemeriksaan mikroskopis meliputi motilitas, viabilitas dan integritas membran plasma. Motilitas yaitu gerakan massa dan individu, viabilitas yaitu spermatozoa hidup dan integritas membran plasma yaitu keutuhan membran menggunakan mikroskop.

\section{Pembuatan Pengencer Tris Kuning Telur}

Langkah pembuatan pengencer tris kuning telur adalah dengan mencampurkan tris amino methane, asam sitrat, laktosa, dan raffinosa pentahydrate ke dalam erlenmeyer kemudian tambahkan aquades dan diaduk hingga homogen. Campuran dimasukkan ke dalam bejana yang berisi air dan dipanaskan secara tidak langsung selama 10 menit hingga suhu mencapai $92-95^{\circ} \mathrm{C}$ kemudian didinginkan secara perlahan hingga mencapai suhu kamar yaitu $20-23^{\circ} \mathrm{C}$. Antibiotik dimasukkan sambil diaduk kemudian ditambahkan kuning telur dan diaduk hingga homogen. Semen yang telah memenuhi syarat pemeriksaan dicampur dengan tris kuning telur dengan perbandingan 1:10.

\section{Pembuatan Pengencer Susu Skim Kuning Telur}

Langkah pembuatan pengencer susu skim kuning telur adalah dengan mencampurkan susu bubuk dengan aquades didalam erlenmeyer dan dipasang termometer berkapasitas $100^{\circ} \mathrm{C}$ atau lebih sehingga mudah dibaca. Erlenmeyer dimsukkan ke dalam bejana berisi air dan dipanaskan secara tidak langsung selama 10 menit sampai suhu mencapai $92-95^{\circ} \mathrm{C}$ kemudian didinginkan secara perlahan hingga mencapai suhu kamar yaitu $20-23^{\circ} \mathrm{C}$. Antibiotik dimasukkan ke dalam susu, diaduk kemudian ditambahkan kuning telur dan diaduk hingga homogen. Semen yang telah memenuhi syarat pemeriksaan dicampur dengan air susu dengan perbandingan 1:10.

\section{Pengamatan Sampel}

Pemeriksaan motilitas dilakukan dengan meneteskan spermatozoa ke atas obyek glass plain kemudian tutup menggunakan cover glass dan diamati dengan mikroskop untuk melihat gerakan progresif spermatozoa.
Pemeriksaan viabilitas dengan menggunakan pewarna eosin nigrosin untuk mewarnai spermatozoa yang mati. Sermatozoa hidup tidak akan terwarnai atau terlihat transparan. Pemeriksaan dilakukan dibawah mikroskop pembesaran 400 kali.

Pemeriksaan integritas atau keutuhan membran plasma dilakukan mengguakan Hypoosmotic Swelling Test (HOS Test). Pengujian dilakukan dengan mencampurkan semen kedalam medium hipoosmotik, didiamkan beberapa saat kemudian meletakkan setetes diatas obyek glass dan ditutup menggunakan cover glass kemudian diperiksa dibawah mikroskop pemesaran 400 kali. Spermatozoa dengan membran plasma utuh akan terlihat pembengkokan atau pembengkakan pada ekor sedangkan spermatozoa dengan membran plasma yang telah rusak maka ekor akan terlihat lurus.

\section{Analisis Data}

Data yang diperoleh diolah menggunakan uji Anova Faktorial. Pengolahan data dengan menggunakan SPSS V.22 (IBM, USA) (Al-Arif, 2016).

\section{HASIL DAN PEMBAHASAN}

Pemeriksaan makroskopis dan mikroskopis dilakukan setelah penampungan semen untuk melihat kelayakan sampel yang akan diberi perlakuan. Hasil pemeriksaan dapat dilihat pada Tabel 1.

Pemeriksaan makroskopis menunjukkan rataan volume $0.87 \mathrm{ml}$, hasil tersebut lebih tinggi dari penelitian Hidayati (2017) yaitu $0.82 \mathrm{ml}$ dan lebih rendah dari penelitian Masyitoh (2018) yaitu $0.94 \mathrm{ml}$. Perbedaan volume semen kambing dari setiap ejakulasi disebabkan oleh pakan, frekuensi penampungan, umur dan faktor lainnya (Salmah, 2014). Warna pada semen dikaitkan dengan kekentalan (konsistensi), semakin kuning - krem warna dari semen maka semakin kental konsistensi yang berarti memiliki konsentrasi yang tinggi. Hasil penelitian menunjukkan rataan warna semen yaitu krem dengan konsistensi kental, hal ini sesuai dengan 
Tabel 1. Hasil pemeriksaan makroskopis dan mikroskopis semen segar kambing Sapera

\begin{tabular}{cc}
\hline Parameter & Hasil Pengamatan \\
\hline Volume & $0.87 \mathrm{ml}$ \\
Warna & Krem \\
Bau & Khas/Prengus \\
pH & 6.56 \\
Konsistensi & Kental \\
Motilitas & $89 \%$ \\
Viabilitas & $96 \%$ \\
Integritas Membran Plasma & $92 \%$ \\
\hline
\end{tabular}

Tabel 2. Motilitas, viabilitas dan integritas membran plasma spermatozoa setelah perlakuan

\begin{tabular}{|c|c|c|c|c|}
\hline Perlakuan & $\begin{array}{c}\text { Waktu } \\
\text { Pengamatan } \\
\text { (Hari) }\end{array}$ & $\begin{array}{c}\text { Motilitas (\%) } \\
(\text { Rata-rata } \pm \text { SD) }\end{array}$ & $\begin{array}{c}\text { Viabilitas }(\%) \\
(\text { Rata-rata } \pm \text { SD) }\end{array}$ & $\begin{array}{c}\text { Integritas Membran } \\
\text { Plasma }(\%) \\
\text { (Rata-rata } \pm \text { SD) }\end{array}$ \\
\hline Tris & 1 & $84.44^{\mathrm{a}} \pm 3.00$ & $89.67^{a} \pm 3.53$ & $83.67^{\mathrm{a}} \pm 3.20$ \\
\hline Kuning & 2 & $60.00^{c} \pm 4.33$ & $67.44^{c} \pm 3.84$ & $63.11^{c} \pm 5.18$ \\
\hline Telur & 3 & $30.00^{\mathrm{e}} \pm 3.54$ & $35.11^{\mathrm{e}} \pm 4.23$ & $23.56^{\mathrm{e}} \pm 3.36$ \\
\hline Susu Skim & 1 & $80.00^{b} \pm 5.00$ & $86.00^{\mathrm{b}} \pm 3.04$ & $79.33^{b} \pm 1.50$ \\
\hline Kuning & 2 & $51.67^{\mathrm{d}} \pm 3.54$ & $61.11^{\mathrm{d}} \pm 5.01$ & $56.33^{\mathrm{d}} \pm 4.00$ \\
\hline Telur & 3 & $19.44^{\mathrm{f}} \pm 1.67$ & $25.56^{\mathrm{f}} \pm 4.27$ & $19.11^{\mathrm{f}} \pm 3.06$ \\
\hline \multicolumn{2}{|c|}{ Perlakuan*hari } & $p<0.05$ & $p>0.05$ & $p>0.05$ \\
\hline
\end{tabular}

penelitian (Hastono dkk. 2013) bahwa semen kambing Sapera berwarna krem dengan konsistensi kental. Hasil pemeriksaan semen menunjukkan bau prengus dengan derajat keasamaan yaitu 6.56. Susilowati dkk., (2010) mengatakan $\mathrm{pH}$ kambing normal berkisar 6.46.8. Penelitian Masyitoh (2018) menunjukkan rataan $\mathrm{pH}$ pada kambing Sapera yaitu 6.50 dan Hidayati (2017) yaitu 6.40.

Hasil pemeriksaan gerakan massa pada penelitian ini adalah (+++), hal ini sesuai dengan penelitian (Hastono dkk., 2013; Hidayati, 2017; Masyitoh, 2018) dimana semen kambing Sapera menghasilkan gerakan massa (+++) yang menunjukkan gelombang yang besar, tebal, gelap dan pergerakan yang cepat. Persentase motilitas yang didapatkan yaitu $89 \%$ dan viabilitas sebesar $96 \%$, hasil tersebut lebih tinggi dibandingkan dengan penelitian Hidayati (2017) yaitu motilitas $75 \%$ dan viabilitas $80 \%$. Penelitian Masyitoh (2018) menunjukkan motilitas $76 \%$ dan viabilitas $81 \%$. Pergerakan spermatozoa menunjukkan tingkat daya hidup spermatozoa yang tinggi.

Presentase motilitas, viabilitas dan integritas membran plasma semen kambing Sapera dalam pengencer tris kuning telur dan susu skim kuning telur pada penyimpanan $5{ }^{\circ} \mathrm{C}$ dapat dilihat pada Tabel 2.

Hasil dari uji Anova Faktorial dapat disimpulkan bahwa pengencer tris kuning telur signifikan $(\mathrm{p}<0.05)$ terhadap susu skim kuning telur pada persentase motilitas, viabilitas dan integritas membran plasma spermatozoa kambing Sapera. Penyimpanan pada hari ke-1 menunjukkan hasil paling signifikan dibandingkan hari ke-2 dan 3 pada motilitas, viabilitas dan integritas membran plasma spermatozoa, terdapat interaksi antara pengencer tris kuning telur dan susu skim kuning telur terhadap lama penyimpanan pada motilitas namun tidak pada viabilitas dan integritas membran plasma spermatozoa kambing Sapera yang disimpan pada suhu $5^{\circ} \mathrm{C}(\mathrm{p}>0.05)$.

Penurunan motilitas, viabilitas dan integritas membran plasma selama proses pendinginan terjadi karena adanya perubahan suhu dan osmolalitas ekstrim sehingga merusak komposisi lipid membran plasma yang berdampak pada penurunan kualitas spermatozoa (Sukmawati dkk., 2014). Penyimpanan semen pada suhu $5^{\circ} \mathrm{C}$ menyebabkan spermatozoa harus beradaptasi 
kembali pada perubahan suhu yang terjadi (Herdis dkk., 2005). Penurunan persentase motilitas spermatozoa pada pengencer susu skim kuning telur disebabkan karena pada tris kuning telur mengandung bahan penyangga dan sumber nutrisi yang lebih lengkap dibanding dengan susu skim kuning telur (Suharyanti dkk., 2011). Spermatozoa yang mengalami kerusakan membran akan mengganggu proses metabolisme sehingga sistesis Adenosin Tri Fosfat (ATP) terhambat dan menyebabkan menurunnya viabilitas spermatozoa (Sukmawati dkk., 2014).

Bahan pengencer tris kuning telur memiliki kandungan yang sesuai dengan syarat bahan pengencer. Syarat bahan pengencer diantaranya memiliki antibiotik, bahan anti cold shock, bersifat buffer dan mengandung sumber nutrisi. Pengencer tris kuning telur mengandung tris amino methane, asam sitrat, laktosa, raffinosa, kuning telur, antibiotik penicilyn dan streptomycin serta aquades (Hardijanto dkk., 2010).

Motilitas, viabilitas dan integritas membran plasma spermatozoa kambing Sapera dapat bertahan dalam pengencer tris kuning telur karena memiliki bahan penyangga dan sumber nutrisi dengan komposisi besar. Bahan penyangga yang terdapat di dalamnya antara lain tris amino methane, asam sitrat, raffinosa dan kuning telur. Bahan penyangga tersebut berfungsi untuk mempertahankan $\mathrm{pH}$ semen dari adanya kejutan dingin (Widjaya, 2011). Kandungan laktosa dalam tris kuning telur berfungsi sebagai sumber nutrisi bagi spermatozoa yang akan dimetabolisme pada proses glikolisis untuk menghasilkan ATP sehingga spermatozoa dapat bergerak dan mempertahankan hidupnya (Rizal dkk., 2008). Selain sebagai bahan penyangga, raffinosa yang merupakan trisakaida (gabungan dari galaktosa glukosa - fruktosa) juga dapat menyediakan lebih banyak sumber nutrisi (Rizal dkk., 2006). Raffinosa yang ditambahkan ke dalam bahan pengencer akan berasosiasi dengan karbohidrat yang terdapat dalam selubung sel spermatozoa sehingga membran plasma dapat terlindungi selama pengolahan semen berlangsung (Nurlia, 2016).
Komposisi pengencer susu skim kuning telur diantaranya susu skim, aquades, kuning telur, gliserol, glukosa dan antibiotik. Bahan pengencer susu skim kuning telur mengandung kuning telur yang terdapat lipoprotein dan lecitin sebagai pelindung membran plasma spermatozoa (Masyitoh, 2018). Susu skim berfungsi untuk mempertahankan osmotik dan keseimbangan elektrolit, glukosa yang terkandung berfungsi sebagai sumber makanan bagi spermatozoa (Indriyanti, 2005).

Penurunan persentase motilitas spermatozoa pada pengencer susu skim kuning telur disebabkan karena pada tris kuning telur mengandung bahan penyangga dan sumber nutrisi yang lebih lengkap dibanding dengan susu skim kuning telur (Suharyanti dkk., 2011). Persentase motilitas, viabilitas dan integritas membran plasma spermatozoa menurun seiring dengan lama waktu pendinginan dan ketersediaan nutrisi (Arifiantini dkk., 2005).

\section{KESIMPULAN}

Dapat disimpulkan bahwa pengencer tris kuning telur paling signifikan mempertahankan kualitas spermatozoa pada aspek motilitas, viabilitas dan integritas membran plasma pada suhu $5^{\circ} \mathrm{C}$.

\section{UCAPAN TERIMA KASIH}

Penulis mengucapkan terima kasih kepada PSDKU Universitas Airlangga di Banyuwangi atas ijin dan fasilitas yang diberikan dalam penelitian.

\section{DAFTAR PUSTAKA}

Al-arif, M.A. 2016. Rancangan Percobaan Fakultas Kedokteran Hewan. Universitas Airlangga.

Allai, L., Xavier, D., Jesus, C., Noureddine, L., Moula, B.M., Abdelmoughit, B., Abdelkhalid, Boubker, N., Bouchra, E.A. 2015. Effect of Argan Oil on Liquid Storage 
of Ram Semen in Tris or Skim Milk Based Extenders. Anim. Reprod. Sci., 4(2), 57-67.

Arifiantiini, L., Yusuf, T.L., Yanti, D. 2005. Kajian Banding Kualitas Semen Beku Sapi Friesian Holstein Menggunakan Pengenceran dari Berbagai Balai Inseminasi Buatan di Indonesia. Animal Production. Hal: 168-176.

Deviana, D., Cahyo, N.P.D., Kumalaningrum, D. R., Kusuma, W.A., Lailiyah, F., Purnama, M.T.E. 2018. Rekayasa Konsentrat Bekatul dengan Tepung Jantung Pisang Dapat Meningkatkan Berat Badan dan Menurunkan Kadar Kolesterol Kambing. Jurnal Sain Veteriner, 36(1), 74-79.

Hardijanto, Susilowati, S., Hernawati, T., Sardjito, T., Suprayogi, T.W. 2010. Buku Ajar Inseminasi Buatan. Surabaya. Airlangga University Press, Hal: 20-24.

Hastono, Adiati, U., Praharani, L. 2013. Libido, Kemampuan Kawin dan Kualitas Sperma Kambing dari Tiga Bangsa. Seminar Nasionan Teknologi Peternakan dan Veterinary: Balai Penelitian Ternak. Bogor. Hal: 345-348.

Herdis, I.W., Darmawan, A., Rizal, M. 2016. Penambahan Beberapa Jenis Gula dapat Meningkatkan Kualitas Spermatozoa Beku Asal Epididimis Ternak Domba. J. Ked. Hewan, 10(2), 200-204.

Hidayati, H. 2017. Imbuhan Pentoxifilline dalam Pengencer Tris Kuning Telur dan Omega-3 dalam Pengencer Skim untuk Meningkatkan Kualitas Semen Beku Kambing Sapera [Tesis]. Program Studi Biologi Reproduksi. Institut Pertanian Bogor. Hal: 12.

Masyitoh, H. 2018. Presentase Motilitas an Viabilitas Spermatozoa Kambing Sapera dalam Pengencer Tris Kuning Telur dan Susu Skim Kuning Telur Before Freezing
[Skripsi]. Fakultas Kedokteran Hewan. Universitas Airlangga. Hal: 23.

Nurlia, I. 2016. Pengaruh Penambahan Dosis Rafinosa alam Pengencer Tris Kuning Telur Terhadap Motilitas, Presentasi Hidup, dan Abnormalitas Spermatozoa Sapi Ongole [Skripsi]. Fakultas Pertanian. Universitas Lampung. Hal: 48.

Rizal, M.A., Herdis. 2008. Peranan Beberapa Jenis Gula dalam Meningkatkan Kualitas Semen Beku Domba Garut. Jurnal Ilmu Ternak dan Veteriner. Hal: 123-130.

Rusdiana, S., Praharani, L., Sumanto, S. 2015. Kualitas dan Produktifitas Susu Kambing Perah Persilangan di Indonesia. Bandan Pertanian. Bogor (Abstr).

Salmah, N. 2014. Motilias, Presentase Hidup dan Abnormalitas Spermatozoa Semen Beku Sapi Bali pada Pengenceran Andromed dan Tris Kuning Telur [Skripsi]. Fakultas Peternakan. Universitas Hasanuddin.

Saputro, A.L., Hamid, I.S., Prastiya, R.A., Purnama, M.T.E. 2018. Hidroponik Fodder Jagung sebagai Substitusi Hijauan Pakan Ternak Ditinjau dari Produktivitas Susu Kambing Sapera. Jurnal Medik Veteriner, 1(2), 48-51.

Suharyati, Hartono, M. 2011. Preservasi dan Krioprotektan Semen Sapi Limousin dalam Berbagai Bahan Pengencer. J. Ked. Hewan, 5(2), 53-58.

Sukmawati, E., Arifiantini, R.I., Purwantara, B. 2014. Daya Tahan Spermatozoa terhadap Proses Pembekuan pada Berbagai Jenis Sapi Pejantan Unggul. JITV, 9(3), 168-175.

Susilowati, S., Hardijanto, Suprayogi, T.W., Sardjito, T., Hernawati, T. 2010. Penuntun Praktikum Inseminasi Buatan. Pusat Penerbit dan Percetakan Unair. Surabaya. Hal: 11-22. 
Widjaya, N. 2011. Pengaruh Pemberian Susu Skim dengan Pengencer Tris Kuning Telur terhadap Daya Tahan Hidup Spermatozoa Sapi pasa Suhu Penyimpanan $5^{\circ} \mathrm{C}$. Jurusan
Produksi Ternak, Fakultas Pertanian Universitas Bandung Raya. Bandung. Hal: 73. 